\title{
Spore Dispersal by Dothistroma septosporum in Northwest British Columbia
}

\author{
Kennedy Boateng and Kathy J. Lewis
}

First author: University of Victoria, Victoria, BC, V8P 5C2, Canada; and second author: University of Northern British Columbia, 3333

University Way, Prince George, BC, V2N 4Z9, Canada.

Accepted for publication 2 July 2014.

\section{ABSTRACT}

Boateng, K., and Lewis, K. J. 2015. Spore dispersal by Dothistroma septosporum in northwestern British Columbia. Phytopathology 105:6979.

We studied spore dispersal by Dothistroma septosporum, causal agent of a serious outbreak of red band needle blight in lodgepole pine plantations in northwest British Columbia. Spore abundance was assessed at different distances and heights from inoculum sources and microclimatic factors were recorded during two consecutive years. Conidia were observed on spore traps from June to September during periods of rainfall. It was rare to detect spores more than $2 \mathrm{~m}$ away from inoculum sources. The timing and number of conidia dispersed were strongly tied to the climatic variables, particularly rainfall and leaf wetness. Should the trend toward increased spring and summer precipitation in the study area continue, the results suggest that disease spread and intensification will also increase. Increasing the planting distances between lodgepole pine trees through mixed species plantations and overall reduction in use of lodgepole pine for regeneration in wet areas are the best strategies to reduce the spread of the disease and enhance future productivity of plantations in the study area.

Additional keyword: ascospores.
Dothistroma (red band) needle blight is an important disease affecting pine plantations in many parts of the world (8). The disease is caused by two species of Dothistroma: Dothistroma septosporum is distributed throughout much of the world, whereas $D$. pini has been reported primarily from the northcentral United States (4). Historically, the disease was most prevalent in pine plantations in the southern hemisphere, particularly in New Zealand, where the main host was radiata pine (Pinus radiata), introduced for timber production. Genetic analysis of isolates from New Zealand and other southern-hemisphere countries have shown no genetic diversity (26), suggesting that the fungus was introduced and has propagated as a single clone ever since. This was supported by Groenewald et al. (25), who showed that, although the fungus was heterothallic, only one mating type allele was present in New Zealand and other southern-hemisphere countries. In contrast, in North America and Europe, both mating types have been detected (25). Funk and Parker (18) identified the teleomorph (Mycosphaerella pini) from needles of both exotic and native pine in southern British Columbia. They observed ascospore production in late spring and early summer, commencing 1 month after the start of conidia production.

Following these early studies and up to the late 1990s, the fungus was commonly identified in British Columbia but caused little damage (27). In the last decade, however, Dothistroma needle blight has caused serious damage in plantations of lodgepole pine ( $P$. contorta var. latifolia) in northwestern British Columbia, and has killed mature trees due to repeated years of defoliation. The current epidemic has caused stocking failure of some lodgepole pine plantations (43) and, according to a 2008 aerial overview survey, 53,505 ha of lodgepole pine stands were

Corresponding author: K. J. Lewis; E-mail address: Kathy.Lewis@unbc.ca

http://dx.doi.org/10.1094/PHYTO-06-13-0175-R

(c) 2015 The American Phytopathological Society affected to some extent by Dothistroma needle blight with damage concentrated near the Bulkley, Kispiox, and Skeena Rivers (42).

D. septosporum is a foliar pathogen and completes its life cycle on the foliage of its host. Conidia are thought to be the primary means of spread of the pathogen $(10,28)$, and are produced in stromata within the host needle (21). Peterson (35) found that, in Nebraska, stromata erupt through the needle epidermis in spring to early summer, and conidia are released until late summer or early fall. Dispersal of conidia is primarily through rain splash (35), and timing of spore production and dissemination is influenced by regional climatic conditions and by variation in local weather patterns $(21,35)$. Current-year and older needles are susceptible to infection by germ tubes that penetrate the needle stomata $(6,35)$.

Reconstruction of past outbreaks using dendrochronology has shown that the disease has existed in northwestern British Columbia since at least the 1830s (the extent of the tree ring record) but outbreaks have been increasing in frequency, severity, and synchronicity (40). This has been attributed to increased spring precipitation $(41,44)$ and August minimum temperatures (41), leading to greater relative humidity $(\mathrm{RH})$ at night. Increased precipitation and RH enhance dispersal of conidiospores (28).

Spore dispersal by rain splash occurs over relatively short distances (15) compared with dispersal by wind $(11,15)$. Ascospores of $M$. pini are thought to be wind-dispersed $(6,21)$; therefore, the longer-distance dispersal of the teleomorphic stage could explain the high level of genotypic diversity and gene flow observed in populations of D. septosporum in northwestern British Columbia compared with other regions of the world where the teleomorph is not present (12).

The severity of Dothistroma needle blight outbreaks in northern British Columbia was the subject of several studies from 1963 to present $(33,44)$ but information on epidemiology, specifically spore dispersal patterns and distances, and the relationship between these processes and climatic factors was lacking. Studies in New Zealand on $P$. radiata have shown that the severity of 
infection by $D$. septosporum depends on temperature, leaf wetness period, and inoculum density (number of infective units in a given area) (9). Infection and development of symptoms can occur between 5 and $26^{\circ} \mathrm{C}$, with infection at lower temperatures thought to be dependent on extended periods of humidity (24).

The purposes of this study were to determine the spatial pattern, timing, and range of spore dispersal by $D$. septosporum, and to examine the influence of climatic variables on spore dispersal in northwest British Columbia. The specific objectives were to (i) determine the relative frequency of ascospores and conidia in rainwater and air; (ii) determine the dispersal gradient of conidia and ascospores, if present, from a point source in the field under natural conditions; (iii) determine the temporal pattern of spore dispersal by D. septosporum during the study period; and (iv) quantify the effect of climatic variables (rainfall, temperature, $\mathrm{RH}$, and leaf wetness) on the timing of dispersal and number of spores dispersed.

\section{MATERIALS AND METHODS}

Spore dispersal and climate data. This study was conducted within the Bulkley Timber Supply Area (TSA) of the Skeena Stikine Forest District in northwest British Columbia (Fig. 1). The study area was located within the Interior Cedar-Hemlock moist cold Hazelton biogeoclimatic variant (ICHmc2) (3), which is found at lower elevations along river valleys and has some of the most productive forests in the interior of British Columbia. Two sites were selected in severely attacked lodgepole pine plantations within the study area. The selected plantations were between 15 and 20 years old and were located $\approx 4 \mathrm{~km}$ apart. Three plots were established at each site, each plot a minimum of $100 \mathrm{~m}$ apart. Plots were located a minimum of $40 \mathrm{~m}$ from road and cut-block boundaries, on relatively flat areas that contained trees showing moderate to severe Dothistroma needle blight. All plots were between 400 and $600 \mathrm{~m}$ in elevation and positions were recorded with a handheld GPS unit (GPS Map 78; GARMIN International, Inc., Olathe, KS). A single lodgepole pine tree infected with Dothistroma spp. was retained at the center of each plot and all other pine trees within a $10-\mathrm{m}$ radius were cleared by cutting and removing all the cut trees in order to create a point source for spore dispersal.
To determine how far the spores dispersed, spores were sampled passively with microscope slides which had an exposed sampling surface area of $10 \mathrm{~cm}^{2}$ covered with a thin coat of Vaseline (Unilever Canada, Toronto, ON, Canada) (5,36). Slides were attached to upright supports at an angle of $45^{\circ}$ slanted toward the tree at two different heights above the ground. The lower slides were fixed at the height of the lower live crown and the upper slides were $50 \mathrm{~cm}$ higher. Four supports were arranged in lines at distances of 0 (beneath sampled tree), 1, 2, and $3 \mathrm{~m}$ from the tree's stem on two opposite sides of each sampled tree (oriented north to south), for a total of 48 slides per site (Fig. 2). All exposed slides were collected and replaced with fresh slides every 3 days from 30 May to 26 September 2009. The collected slides were observed under a compound microscope at $\times 100$ magnification to count the number of spores collected over the $10-\mathrm{cm}^{2}$ sampling surface on each slide. The exposed slides were collected 34 times at both study sites during the 2009 sampling period. To facilitate spore counting and for accuracy, the exposed sampling area of each slide was divided into four quarters and spores on two randomly selected quarters were counted. Identification was based on the morphology of D. septosporum as described by Funk (17). Moreover, to aid the identification, conidia of Dothistroma were extracted from a fruiting body on an infected needle, prepared in $10 \% \mathrm{KOH}$, and observed on a microscope slide under a compound microscope to compare with the spores observed on the slides that were collected from the field. This passive spore sampling was repeated in 2010 to determine whether the commencement of Dothistroma spore dispersal differed from that in 2009 , and to determine how climate variability during the two seasons influenced the timing and number of spores dispersed. This second-year sampling lasted for 9 weeks, from 23 April to 28 June, on one plot per site. Rotorod spore traps were suspended in the canopy in 2009 in an attempt to trap airborne spores within the live crown.

All six plots were equipped with HOBO sensors (HOBO Pro Series; Onset, Bourne, MA) and microclimate loggers (Micro Station Data Logger H21-002; Onset) to record the air temperature $\left({ }^{\circ} \mathrm{C}\right), \mathrm{RH}(\%)$, and leaf wetness $(\%)$ at 15 -min intervals throughout the sampling period in each year. The microclimate loggers were established $\approx 5 \mathrm{~m}$ from the edge of the cleared plot. One rain gauge was mounted at each site to record the cumulative

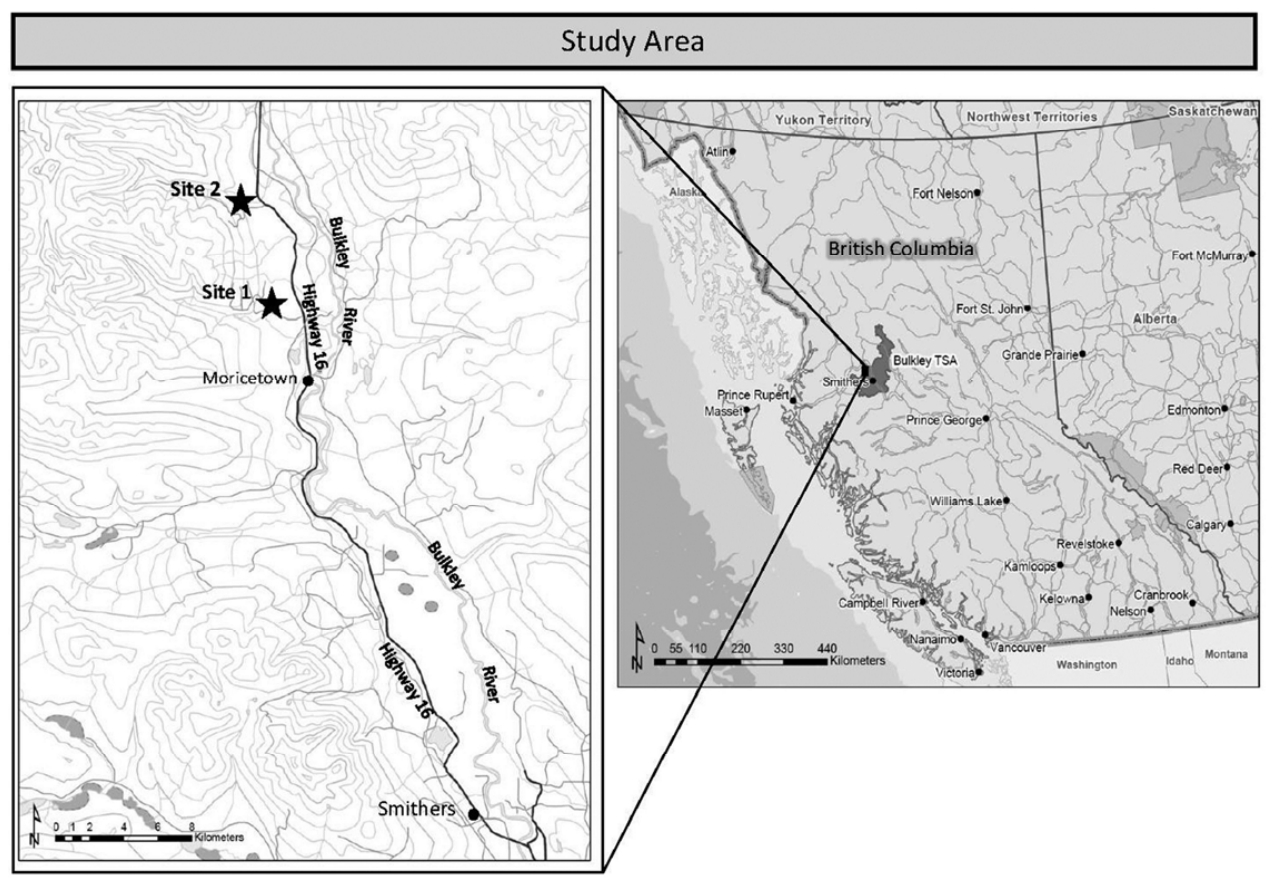

Fig. 1. Map of the study area showing the location of the two study sites. Inset map of British Columbia showing the location of the study area. 
rainfall (in millimeters) collected every 3 days throughout the study period.

Rain collection and spore sampling. Rain collectors were mounted on stands $\approx 3 \mathrm{~m}$ above the ground and placed just outside each plot to catch rain-dispersed spores. In total, 12 rain collectors were used, with 2 at each plot. The rainwater was collected every 3 days whenever rain fell during the 2009 field season and refrigerated at $4{ }^{\circ} \mathrm{C}$ to inhibit spore germination. Benomyl 50 systemic fungicide (3 g/liter of water; Later Chemical Ltd., Richmond, British Columbia) was added to the collected rainwater in an attempt to prevent the collected spores from germinating during transportation. Each water sample $(100 \mathrm{ml})$ was prefiltered with a $125-\mu \mathrm{m}$ mesh sieve (Endecotts Ltd., London) to remove debris and then vacuum filtered through a nitrocellulose membrane filter (Millipore Corp., Billerica, MA) with a pore size of $0.8 \mu \mathrm{m}$ to trap spores. The Millipore filter was transferred with smooth-tip forceps to a clean petri dish, and then cleared with nondrying immersion oil (type B) for microscopy (Gargille Laboratories, Cedar Grove, $\mathrm{NJ}$ ) and observed under a compound microscope at $\times 400$ magnification for spore counting. A $5-\mathrm{cm}^{2}$ area of the Millipore filter was observed to facilitate counting of the spores. Despite the low storage temperature and fungicide treatment, the spores still germinated during storage, which impaired the accuracy of spore counts. Therefore, the numbers of spores observed on the $5-\mathrm{cm}^{2}$ section of filter were categorized ( $0=$ no spores, $1=1$ to $25,2=26$ to $50,3=51$ to $75,4=76$ to $100,5=101$ to $200,6=201$ to 499 , and $7=\geq 500$ ). Rainwater was collected 17 times at the two study sites during the 2009 sampling period.

Data and statistical analysis. Data collected during the 2009 field season were used for all statistical analyses because sampling during the 2010 field season was primarily intended for comparing the start of spore dispersal with 2009. All statistical tests and model construction used the statistical software R 2.4.1 (R Development Core Team, Vienna). Daily means of 24-h temperature, $\mathrm{RH}$, leaf wetness, and cumulative rainfall recorded every 3 days throughout the study period were calculated. The mean minimum overnight temperatures at the two study sites were also recorded. The number of conidia of D. septosporum collected every 3 days on $10 \mathrm{~cm}^{2}$ of the lowest slide at the $1-\mathrm{m}$ distance for each row was averaged for each of the sites. Numbers of spores recorded on the slides and in the rainwater were plotted separately for each site and analyzed graphically to determine the relative numbers of conidia dispersed in air and rainwater during the 2009 sampling period. The frequency of ascospores could not be determined because none were trapped during the study. To determine whether more spores were collected from the lower or upper slides, the average number of spores observed every 3 days at the 1-m distance at each of the two sampling heights was plotted over time for each of the sites. A one-way between-subjects analysis of variance (ANOVA) was conducted to compare the effect of sampling heights on the number of spores collected from the 1-m distance. The response variable was transformed with $\log (x+1)$ transformation to satisfy assumptions of ANOVA because the data contained many zeros. To determine how far the spores dispersed and from which distance the greatest number of spores were collected, the average number of spores trapped at each distance every 3 days was plotted over time for each of the sites. The relationship between horizontal distance from inoculum sources and spore count was modeled using regression analysis with linear mixed effects. Distance was treated as a fixed effect and fit as a continuous variable, while sites and trees were treated as random effects due to the site-to-site and tree-to-tree variation.

Multiple regressions with mixed effects were used to explore and model the effects of the climatic variables on the number of spores dispersed. Spore count from the lower slides positioned $1 \mathrm{~m}$ horizontally from inoculum sources was the response variable. Climatic variables were treated as fixed effects and fit as con- tinuous variables while sites, trees, and collection dates were treated as random effects. The correlations between the climatic variables were tested and one of two highly correlated variables was omitted from the regression models. The models were checked with residuals plots; then, the response variable was transformed with $\log (x+1)$ because the data contained many zeros. A backward elimination procedure was used to selectively eliminate the least significant variables in an iterative model-fitting procedure until all remaining variables were significant. Concurrently, we examined Akaike Information Criterion (AIC) values and reported models with lowest AIC values and statistically significant explanatory variables using $\alpha=0.05$.

\section{RESULTS}

Temporal pattern of spore dispersal. Throughout the study period in both 2009 and 2010, ascospores (sexual spores) of D. septosporum were not observed. Only conidia (asexual spores) were trapped on both the microscope slides and in the rainwater. The conidia trapped on the slides were mostly concentrated in water droplets that had collected on the slides; these spores were elongated, straight, and hyaline with one to five septa. On average, the dimensions of most conidia trapped were 14 to 40 by 2 to $3 \mu \mathrm{m}$. Neither conidia nor ascospores were observed on the rotorod traps that were mounted in the upper canopy.

Spore sampling started on 30 May 2009 and, for almost the first 3 weeks ( 30 May to 17 June) of sampling at both sites, no spores were observed by any of the sampling methods. On 20 June, the first spores were observed on the microscope slides and in the collected rainwater of both study sites (Fig. 3A and B). During the 2010 field season, spore sampling started on 23 April and, similar to the previous season, no spores were observed until 10 June. Results from the 2009 sampling season indicated that the numbers of spores collected on the slides increased when it rained

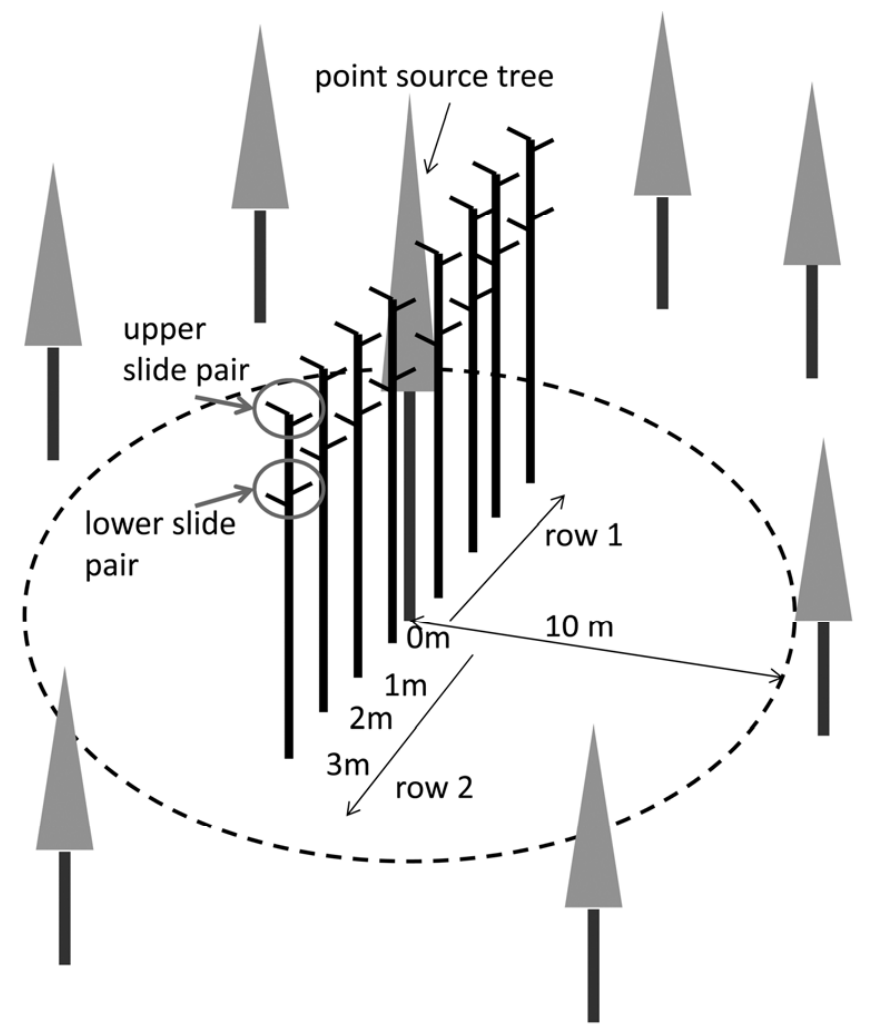

Fig. 2. Locations of microscope slides (spore samplers) and retained infected lodgepole pine tree (point source tree) used to determine the dispersal distance of Dothistroma spores in the Bulkley Timber Supply Area in northwest British Columbia, Canada in 2009 and 2010. 
after the first observation on 20 June, reaching a peak on 20 July, and decreasing by the second week in September. No spores were collected between 22 July and 7 August at both sites and spores were absent on the slides and in the rainwater on the last day of sampling (26 September), despite the fact that rainfall was recorded. The 9-week sampling period in 2010 also showed increases in the number of spores dispersed after the first observation on both sites.

Relationship between conidial dispersal and climatic variables. During the 2009 sampling period, the cumulative rainfall over 3-day periods ranged between 0 and $21 \mathrm{~mm}$ at site 1 , with an average of $5.9 \mathrm{~mm}$, and between 0 and $23.5 \mathrm{~mm}$ at site 2, with an average of $5.3 \mathrm{~mm}$. No rainfall was recorded throughout the first 2 weeks of sampling (30 May to 14 June) at both sites in 2009. There was a prolonged dry period at both sites during the 9th and 10th weeks of sampling (22 July to 7 August 2009) (Fig. 4A). Because both study sites had similar rainfall, temperature, $\mathrm{RH}$, and leaf wetness, we only show the data for site 1 (Figs. 4A and B and $5 \mathrm{~A}$ and $\mathrm{B}$ ).
The daily mean temperature recorded across the three plots at each site during the 2009 sampling period was 9.8 to $22.7^{\circ} \mathrm{C}$, with an average of $14.3^{\circ} \mathrm{C}$, at site 1 ; and 8.9 and $23.1^{\circ} \mathrm{C}$, with an average of $14.5^{\circ} \mathrm{C}$, at site 2 (Fig. 4B). The mean minimum overnight temperatures were -0.7 to $11.4^{\circ} \mathrm{C}$ at site 1 and -0.9 to $11.7^{\circ} \mathrm{C}$ at site 2 . Temperature was negatively correlated with rainfall $(r=-0.46)$. The daily mean percent $\mathrm{RH}$ across the three plots at each site varied from 57.0 to $88.7 \%$, with an average of $74.9 \%$, and from 53.6 to $91.5 \%$, with an average of $76.5 \%$ at sites 1 and 2, respectively. Daily mean RH was high at the end of August through to the end of September during the 2009 sampling period at both sites (Fig. 5A). Mean daily leaf wetness across the three plots at each site was 15.0 to $75.2 \%$, with an average of $43.3 \%$ at site 1 (Fig. 5B), and 0.9 and $83.8 \%$, with an average of $44.7 \%$, at site 2 . Leaf wetness and RH were strongly correlated $(r=0.65)$

Conidia were only observed on the slides whenever rain fell throughout both sampling seasons after the first conidia were observed. A small amount of rainfall, as low as $0.5 \mathrm{~mm}$, triggered
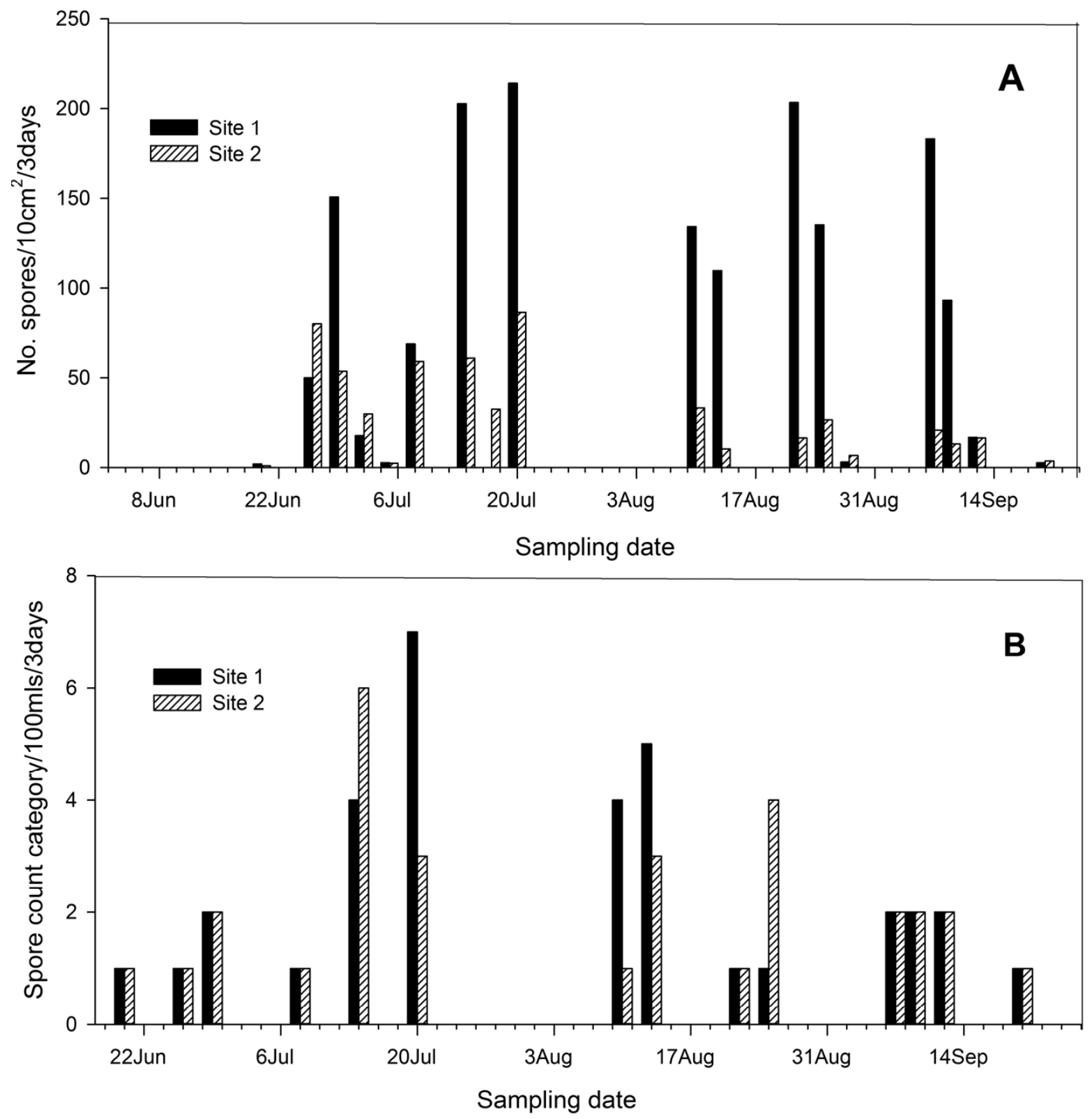

Fig. 3. A, Mean count of conidia collected on the lower microscope slides positioned $1 \mathrm{~m}$ horizontally from inoculum sources and $\mathbf{B}$, mean count of conidia in the rainwater, with categories as follows: $1=1$ to $25,2=26$ to $50,3=51$ to $75,4=76$ to $100,5=101$ to $200,6=201$ to 499 , and $7=\geq 500$, collected at the two study sites during the 2009 sampling period in the Bulkley Timber Supply Area in northwest British Columbia, Canada. 
release and dispersal of spores. An increase in rainfall amount resulted in greater numbers of conidia disseminated but rainfall frequency was more important than rainfall amount. Dispersal peaked at site 1 and site 2 on 20 July 2009, when cumulative rainfall over 3 days was 17 and $15 \mathrm{~mm}$, respectively (Fig. 4A). Dispersal of conidia of $D$. septosporum was significantly associated with rainfall, leaf wetness, $\mathrm{RH}$, and temperature (Table 1); however, no conidia were observed on rainless days regardless of the temperature and $\mathrm{RH}$. The number of spores dispersed was negatively associated with temperature. Most spore release and dispersal occurred with daily mean temperatures between 9.6 and $17.6^{\circ} \mathrm{C}$, and a few or no spores were observed when temperature was $\geq 18^{\circ} \mathrm{C}$ in 2009 (Fig. 4B). From the regression results, daily mean temperature significantly influenced the number of conidia dispersed during the sampling period in 2009 (Table 1). The mean minimum overnight temperature had no significant relationship with the number of spores collected $\left(t_{197}=-0.725, P=0.470\right)$.
Most conidia were collected when the mean daily $\mathrm{RH}$ during the sampling period in 2009 was 78.7 to $85.4 \%$ and the mean daily leaf wetness was 48.1 to $75.1 \%$. The number of conidia collected on the slides was significantly related to $\mathrm{RH}$ and percent leaf wetness (Table 1). Generally, a few or no conidia were trapped when $\mathrm{RH}$ was $<65 \%$ (Fig. 5A) and leaf wetness was $<40 \%$ at both sites (Fig. 5B). The average number of conidia trapped increased with increasing rainfall, $\mathrm{RH}$, and leaf wetness but decreased with increasing temperature. From the results of multiple regression models with mixed effects, all the climatic variables were significantly correlated with spore abundance. $\mathrm{RH}$ was omitted from the final model because it was highly correlated with leaf wetness, and leaf wetness had a better predictive power. Therefore, the best model for the effects of climatic factors on conidia dispersal was the regression equation $\log _{10} y=-0.197+$ $0.042 x_{1}+0.030 x_{2}$, where $\mathrm{y}$ is the average number of conidia per $10 \mathrm{~cm}^{2}, x_{1}$ is mean amount of rainfall over a 3-day period in
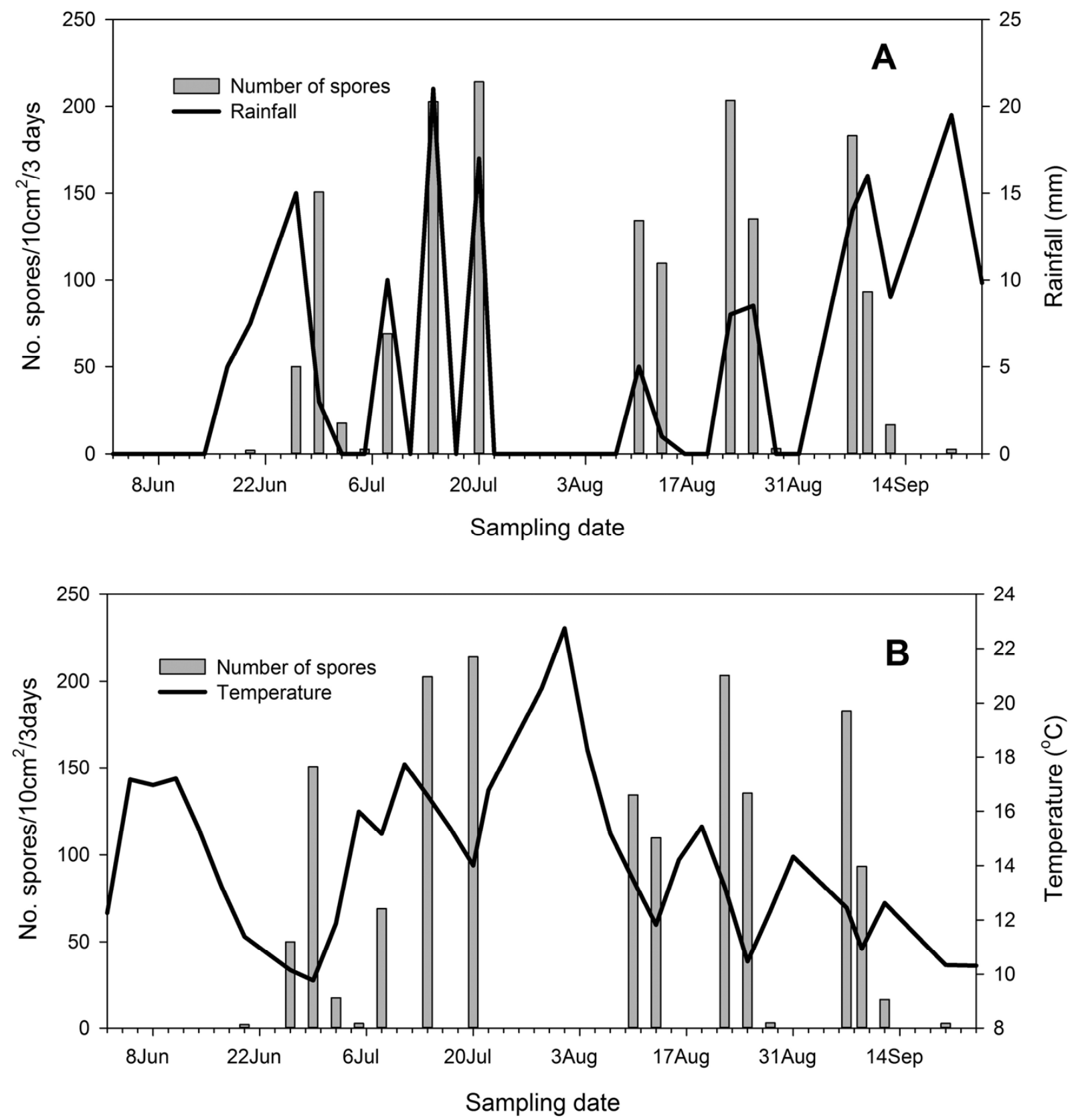

Fig. 4. A, Relationship between mean counts of conidia collected on the lower microscope slides positioned $1 \mathrm{~m}$ horizontally from inoculum sources and cumulative rainfall over a 3-day period and B, daily mean of 24-h temperature at site 1 in the Bulkley Timber Supply Area in northwest British Columbia, Canada in 2009. 
millimeters, and $x_{2}$ is daily mean leaf wetness in percentage (Table 1). This relationship holds for a cumulative rainfall over a 3-day period between 0 and $23.5 \mathrm{~mm}$ and daily mean leaf wetness between 0.9 and $83.8 \%$ recorded during this study.

Distance and height of conidia dispersal from inoculum sources. The greatest number of conidia were observed on the slides positioned directly beneath the crowns of sampled trees and up close to the stem, followed by those positioned $1 \mathrm{~m}$ away from the stem of the sample tree. It was rare to observe spores on the slides positioned 2 and $3 \mathrm{~m}$ away from the stem of the sample tree (Fig. 6A and B). The number of conidia trapped at both sites throughout the sampling period significantly decreased with increasing distance from the inoculum source $\left(t_{611}=-18.187, P<\right.$ $0.001)$. Regression equation $\log _{10} y=1.849-0.649 x$ best fit the relationship between distance and spore counts, where $y$ is the average number of conidia collected during the sampling period from each distance at both sites and $x$ is distance from the inoculum source. This relationship holds for numbers of conidia sampled at distances of $0,1,2$, and $3 \mathrm{~m}$ from inoculum sources within the study area. Moreover, the average number of spores trapped on the lower slides at the 1-m distance at each site were slightly higher than the number trapped on the upper slides (Fig. 7A and B) but there was no significant difference between the two sampling heights at both sites $(F[1,406]=0.2343, P=0.6286)$.

\section{DISCUSSION}

The purpose of this study was to quantify the spatio-temporal pattern of spore dispersal by $D$. septosporum and the relationship with climate. Analysis was limited to asexual spores because ascospores were never observed during the study. Several lines of evidence suggest that sexual reproduction is an important component of the population dynamics of $D$. septosporum in the study area. Dale et al. (12) found a high level of genotypic variability among isolates obtained between and within sites, and even from isolates taken from infected needles within a single tree. They concluded that sexual reproduction was the main reason for this variability, which is supported by the findings of Groenewald et
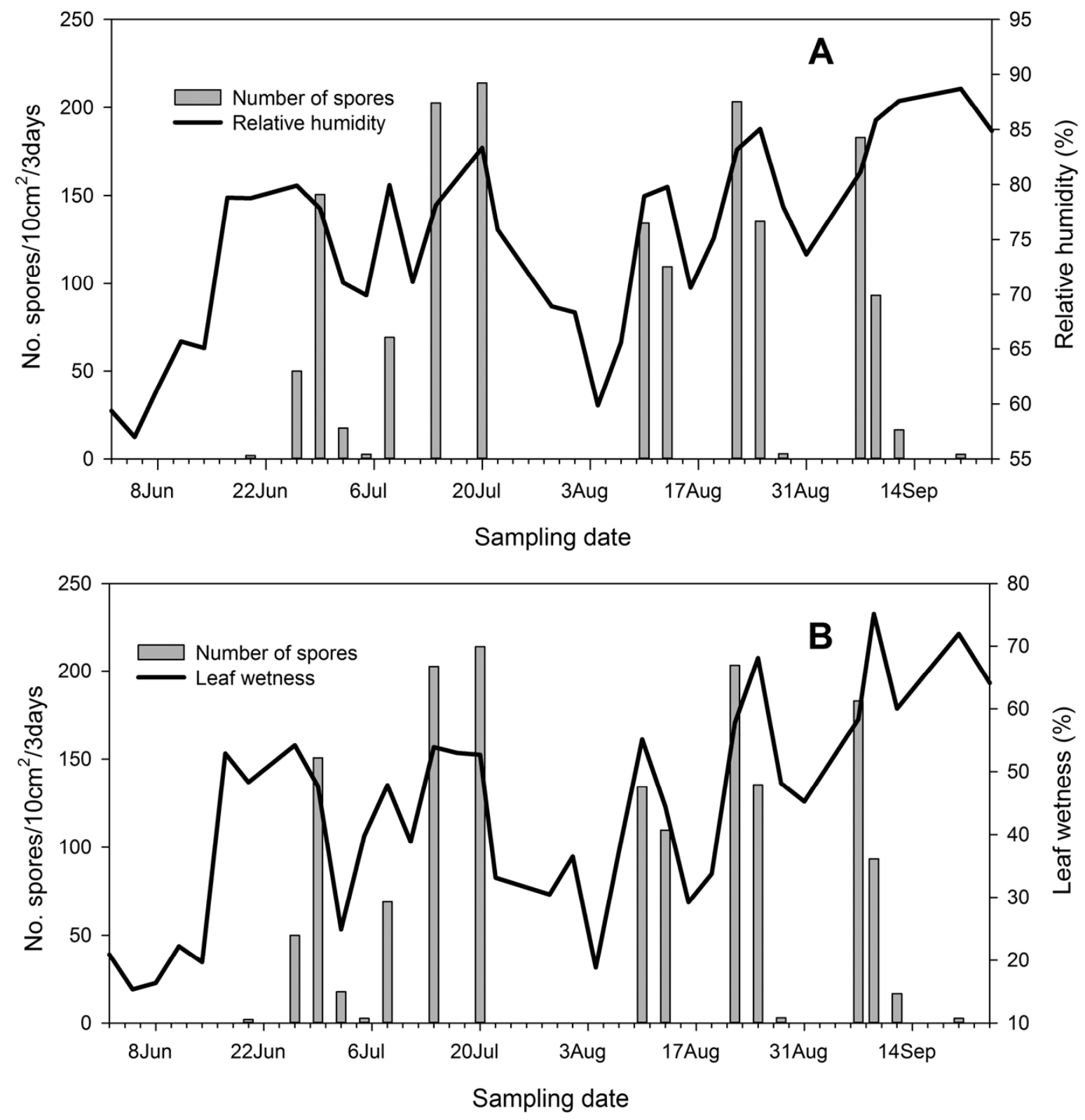

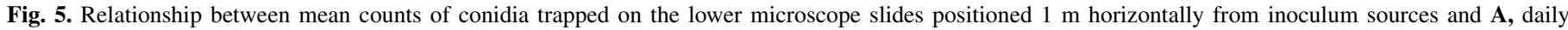

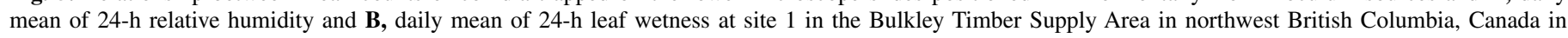
2009. 
al. (25), who showed that both mating types of the fungus were present in isolates from the same area. Despite this evidence of sexual reproduction, only asexual spores were detected in the current study. This may have resulted from the sampling methods used, which may not have been appropriate for collecting ascospores. This is supported by Braun (7), who sampled and dissected fruiting bodies from trees and found only two ascomata from 2,670 fruiting bodies. It is also possible that the timing of the sampling period missed ascospore production or that, during conducive weather conditions which accompany outbreak periods, the production of ascospores declines in favor of the production of conidia. Further, Evans (14), who sampled forests in several countries in Central America where both the teleomorph and the anamorph were present, found that early collections were dominated by the sexual stage whereas later collections were primarily conidia. Evans suggests that favorable ambient conditions enable greater production of asexual spores, thereby increasing their relative abundance. Evidence from previous studies $(7,12,25)$ suggests that the sexual spores of the fungus exist in northwest British Columbia and have a significant impact on the population structure (12). Other spore-trapping studies in areas where genetic evidence supports the existence of sexual reproduction have also not yielded ascospores. Investigations over a 5-year period by Peterson (35) in eastern Nebraska and a 3-year investigation by Bingzhang et al. (5) in China yielded no ascospores, despite genetic evidence that suggested that sexual reproduction of the fungus occurred in Nebraska (25). Markovskaja and Treigiene (30) also found no teleomorphic stage in their study to evaluate the spread of Dothistroma spp. on P. sylvestris in eastern, central, and southern parts of Lithuania and reported that only the anamorphic stage was responsible for the disease on needles of $P$. sylvestris. Barnes et al. (4) reported that the teleomorph M. pini was not observed in Dothistroma samples collected from different areas, including British Columbia and Nebraska, where evidence of sexual reproduction was found (25). Collectively, these studies suggest that the role of ascospores in disease spread in northern British Columbia during conditions conducive to disease devel- opment is likely quite limited, which is consistent with studies in other countries where the teleomorph stage is present $(10,28)$.

Dispersal of Dothistroma conidia started in June, even though spore sampling started on 30 May 2009 and 23 April 2010. Conidia were first trapped on 20 June 2009 and 10 June 2010. Spore dispersal peaked on 20 July 2009, similar to results from Braun (7), who found that fruiting bodies first appeared on the needles in late May, with a peak from July to August, but spores were not detected until late June with a peak in July. In 2009, when traps were monitored from 30 May to 26 September, most conidia were collected in two periods, from 26 June to 20 July and from 10 August to 20 September, which suggests that Dothistroma spores were dispersed when conditions were conducive for spore production, release, and dissemination. Field investigations by Peterson (35) in Nebraska found high numbers of spores were produced during June, July, August, and September, with no conidia trapped in October in 4 of 5 years despite significant rainfall in October. Peterson (35) and Bingzhang et al. (5) reported that conidia were first trapped in May (although, in the Peterson study, the numbers were very low), with peak conidia dispersal in June and July (5). The later commencement of spore dispersal in our study was probably due to colder temperatures (mean temperature of $19.3^{\circ} \mathrm{C}$ in May in Nebraska during 1 year of the study compared with $<12^{\circ} \mathrm{C}$ in our study area) and drier conditions in May and early June, which slowed development of the fruiting bodies and spore production. Although fruiting bodies were present on infected needles in late May near our study area, high numbers of fruiting bodies were not observed until early June and spore production began in late June (7). Despite conducive weather for spore production and dispersal, the number of spores trapped at both study sites started decreasing from mid-September and no spores were collected in late September, which was slightly earlier than the cessation of spore production in Peterson's study (35). The factors that influence cessation of spore production are not known but could include slower metabolism by the fungus due to reductions in temperature (29), and exhaustion of the resources available to the fungus for reproduction.

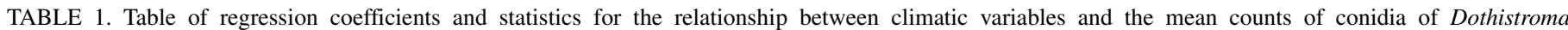
septosporum on slides placed at the base of the canopy and at $1 \mathrm{~m}$ from an infected tree

\begin{tabular}{|c|c|c|c|c|c|}
\hline Regression, variable $^{\mathrm{a}}$ & Coefficient & $\mathrm{SE}^{\mathrm{b}}$ & $t$ value & $P$ value & $\mathrm{AIC}^{\mathrm{c}}$ \\
\hline \multicolumn{6}{|l|}{ Univariate $\left(\mathrm{t}_{197}\right)$} \\
\hline Intercept & 0.922 & 0.2340 & 3.94 & 0.0001 & 803 \\
\hline Rain & 0.079 & 0.0116 & 6.87 & 0.001 & $\ldots$ \\
\hline Intercept & -0.443 & 0.3029 & -1.46 & 0.1451 & 791 \\
\hline LW & 0.042 & 0.0052 & 7.95 & 0.00001 & $\ldots$ \\
\hline Intercept & -5.975 & 0.8966 & -6.66 & 0.0001 & 801 \\
\hline $\mathrm{RH}$ & 0.098 & 0.0114 & 8.51 & 0.0001 & $\ldots$ \\
\hline Intercept & 4.844 & 0.5584 & 8.67 & 0.0001 & 802 \\
\hline Temperature & -0.239 & 0.0359 & -6.63 & 0.0001 & $\ldots$ \\
\hline \multicolumn{6}{|l|}{ Multivariate $\left(\mathrm{t}_{195}\right)$} \\
\hline Intercept & 0.499 & 1.0981 & 0.45 & 0.6503 & 793 \\
\hline Rain & 0.044 & 0.0129 & 3.45 & 0.0007 & $\ldots$ \\
\hline RH & 0.031 & 0.0098 & 3.18 & 0.0017 & $\ldots$ \\
\hline Temperature & -0.108 & 0.0414 & -2.61 & 0.0098 & $\ldots$ \\
\hline Intercept & -1.922 & 0.6913 & -2.78 & 0.006 & 793 \\
\hline Rain & 0.054 & 0.0125 & 4.29 & 0.0001 & $\ldots$ \\
\hline RH & 0.043 & 0.0093 & 4.59 & 0.0001 & $\ldots$ \\
\hline Intercept & -0.197 & 0.3140 & -0.63 & 0.0530 & 790 \\
\hline Rain & 0.042 & 0.0135 & 3.09 & 0.0023 & $\ldots$ \\
\hline LW & 0.030 & 0.0063 & 4.82 & 0.00001 & $\cdots$ \\
\hline Intercept & 3.359 & 0.6333 & 5.3 & 0.001 & 792 \\
\hline Rain & 0.056 & 0.0126 & 4.45 & 0.001 & $\ldots$ \\
\hline Temperature & -0.159 & 0.0387 & -4.12 & 0.0001 & $\ldots$ \\
\hline
\end{tabular}

${ }^{\text {a }} \mathrm{LW}=$ leaf wetness and $\mathrm{RH}=$ relative humidity.

b Standard error.

c Akaike information criterion. 
Conidia dispersal and climatic variables. Climatic factors such as rainfall, temperature, $\mathrm{RH}$, and leaf wetness play important roles in the production, liberation, and dispersal of spores of many foliar pathogens $(1,15)$. During this study, spores were only observed whenever rain fell throughout the sampling period and no spores were trapped on dry days, confirming for northwestern British Columbia that rain splash is the primary means of conidia dispersal, as already demonstrated in other regions $(21,28,35)$. The number of conidia collected was related to rainfall but rainfall frequency was more important than the amount of rainfall. Even as little as $0.5 \mathrm{~mm}$ of rain triggered conidia dispersal. No conidia were observed in the first 2 weeks ( 2 to 17 June) of the 2009 sampling period, despite the presence of fruiting bodies on the needles, which may be attributed to the absence of rainfall during that period. No spores were observed during a prolonged dry period from 22 July to 7 August 2009. The trend observed in 2010 was similar, with no observation of conidia on rainless days even after the commencement of seasonal conidia dispersal. Similar results were observed in Nebraska (35), China (5), and Serbia (28), which all showed that conidia were mainly dispersed by raindrops during wet periods.

In this study, conidia were only dispersed over short distances $(<2 \mathrm{~m})$ and only during rain events. Previous findings on Austrian and ponderosa pine ( $P$. nigra and $P$. ponderosa) plantations in Nebraska (34) and on $P$. radiata and $P$. ponderosa plantations in New Zealand (36) demonstrated that conidia of Dothistroma were seldom trapped beyond 1.5 and $2 \mathrm{~m}$, respectively, from an inoculum source, even during storms with wind speeds up to $64 \mathrm{~km} / \mathrm{h}$. In a study on the assessment and control of Dothistroma needle blight in New Zealand, the dispersal distance of spores of the
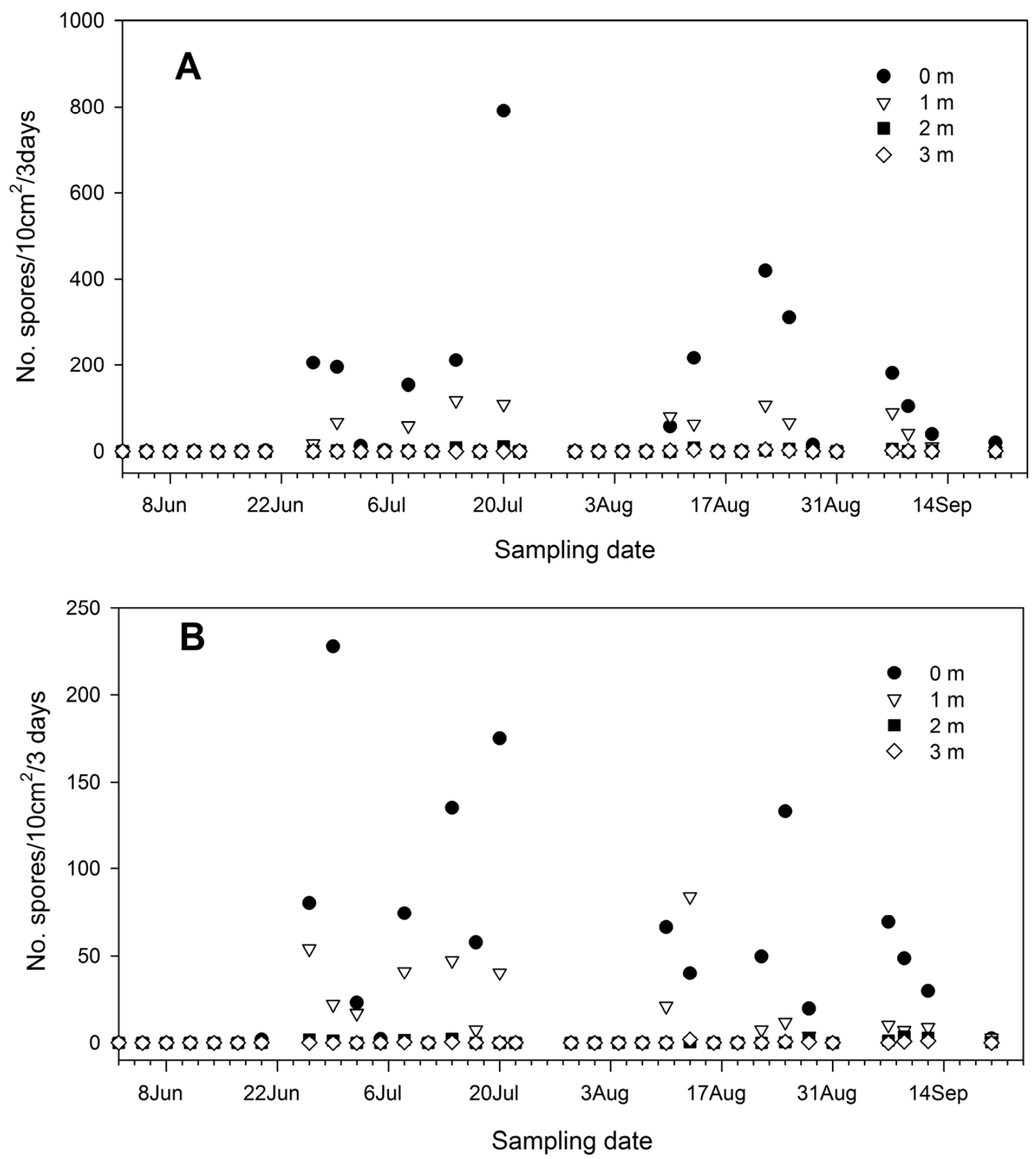

Fig. 6. Mean counts of conidia per $10 \mathrm{~cm}^{2}$ trapped on the lower slides at different distances from inoculum sources at $\mathbf{A}$, site 1 and $\mathbf{B}$, site 2 in the Bulkley Timber Supply Area in northwest British Columbia, Canada, during 2009 sampling period. 
fungus was normally short, although a specific distance was not stated (9). This short dispersal is typical of splash dispersal by rain rather than dispersal by wind, where spores can travel several kilometers (11,15). EPPO/CABI (13) reported that the hyaline nature of conidia makes them less adapted to ultraviolet radiation and, thus, less likely to survive transport by methods other than rain-splash. Dothistroma conidia are produced in mucilage and, in general, spores produced in mucilage are splash dispersed because the mucilage prevents dispersal by wind alone (15). The mucilage surrounding spores protects them from desiccation and the loss of viability during dry weather. Spores formed in mucilage are held firmly to the plant surfaces when dry but readily released when wetted (32). Conidia of D. septosporum also have an elongate shape, which is thought to aid adhesion to host surfaces by reducing surface mobility and is typical of conidia that are mainly splash dispersed over short distances (15). In our study, percent leaf wetness significantly influenced conidia dis- persal, with few or no spores dispersed when percentage leaf wetness was $<40 \%$. This was most likely due to the requirement for moisture to dissolve the mucilage containing the spores, such that they are released in a film of water on the needle surfaces, making them available for splash dispersal. There were periods (e.g., 1 to 5 September) with high leaf wetness $(>45 \%)$ and $\mathrm{RH}$ $(>75 \%)$, which would have dissolved the mucilage, but no spores were collected. Spore dispersal was limited to periods of actual rainfall and not just dew or fog. High leaf wetness and rainfall also favor infection by foliar pathogens such as D. septosporum, because free water is available on the host surface, which promotes spore germination (16).

A study from Kenya found that conidia of D. septosporum could be taken up in clouds and heavy mist, which could result in long-distance dispersal (23); and other studies from Chile, New Zealand, and the United States indicate that conidia dispersal can occur during conditions of heavy mist (21). Long-distance dis-
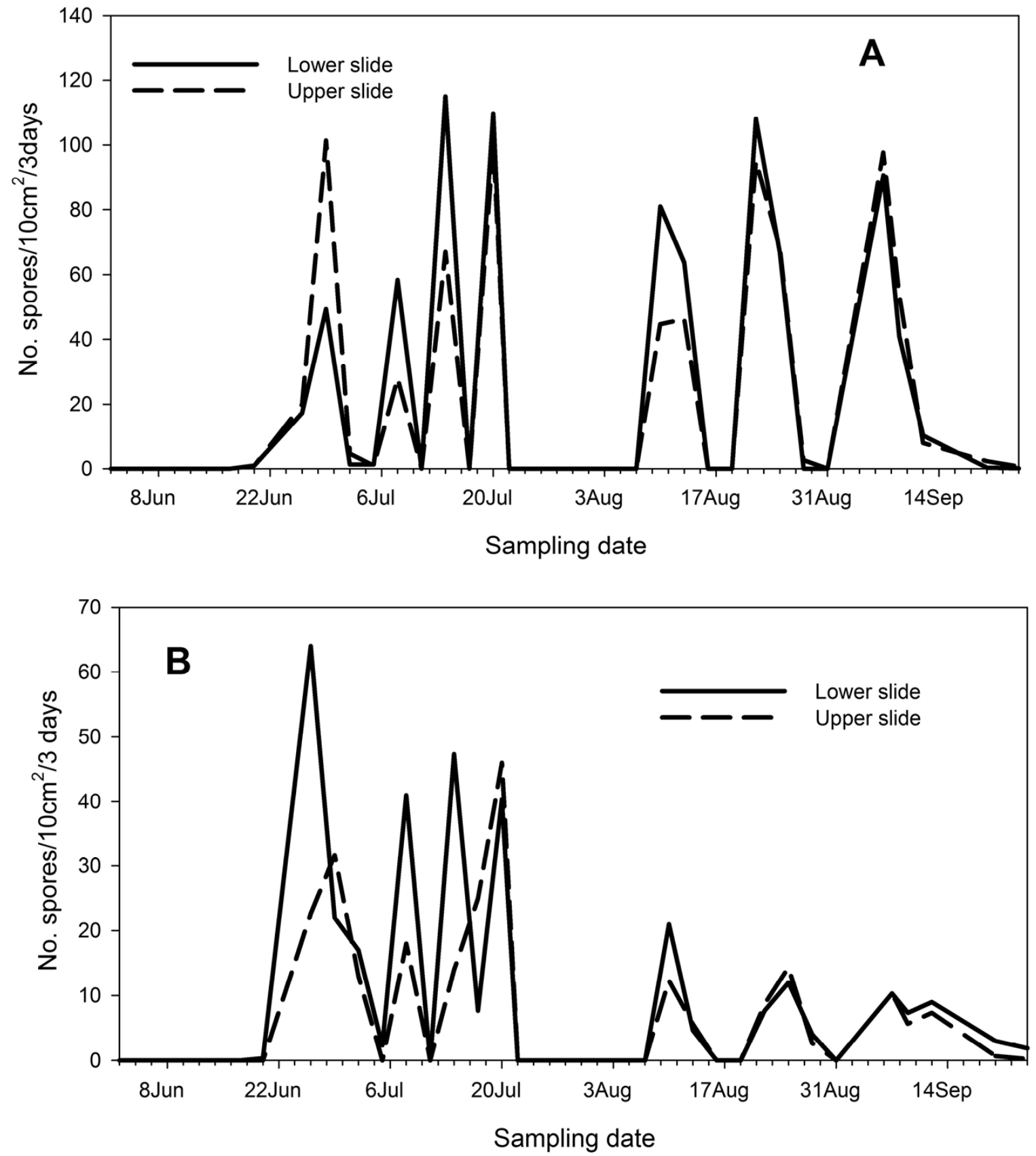

Fig. 7. Mean counts of conidia per $10 \mathrm{~cm}^{2}$ trapped on the lower and upper slides positioned $1 \mathrm{~m}$ horizontally from inoculum sources at $\mathbf{A}$, site 1 and $\mathbf{B}$, site 2 in the Bulkley Timber Supply Area in northwest British Columbia, Canada, during 2009 sampling period. 
persal of conidia in clouds or mist could explain the wide spatial distribution of apparent clones of D. septosporum (12). However, in our study, no spores were trapped on days with high leaf wetness and RH but without rainfall, although the study was not designed to specifically examine spore dispersal under mist and fog conditions.

Red band needle blight usually starts in the lower crown, where infection and defoliation are greatest (2). As expected, we found that the average number of conidia trapped on the lower slides was slightly higher than that of the upper slides but the difference was not statistically significant. Large numbers of conidia were trapped on the upper slides, which were only $0.5 \mathrm{~m}$ above the most severely infected part of the crown. The findings on horizontal and vertical dispersal distance also support previous reports that spread of Dothistroma spp. occurs within and between neighboring trees (8), and that rain splash plays an important role in disease intensification (37) as well as horizontal spread.

Mean daily temperature was negatively correlated with the number of spores collected, and was also negatively correlated with $\mathrm{RH}$ and leaf wetness. Therefore, although the optimum temperatures for growth of the fungus and spore germination were fairly warm at 20 and $22^{\circ} \mathrm{C}$, respectively (29), we found a negative effect of increasing temperature on conidia dispersal which was probably due to the related dry conditions rather than the direct effect of temperature. No rainfall was recorded when the mean daily temperature was $>18^{\circ} \mathrm{C}$ and no spores were collected during those periods. Despite these findings, since the 1970s, the study area has experienced increased precipitation during midsummer, including rainy periods with mean daily temperatures $>18$ and $20^{\circ} \mathrm{C}$. A high frequency of warm rain events in the mid- to late 1990s was found to coincide with a sharp increase in the extent and severity of red band needle blight (44). Therefore, although temperature may contribute to development and maturation of spores (28) or to their germination rate, in our study area, when warm temperatures occur without rainfall, spore dispersal ceases. Our findings are consistent with other studies in New Zealand and the central United States, which also found that dry conditions during periods with high temperatures negatively affects spore dispersal $(9,21,34)$.

Management implications and strategies. The heavy use of preferred commercial species such as lodgepole pine and spruce (Picea sp.) to reforest cutover areas in British Columbia has played an important role in the severity of the current epidemic of Dothistroma needle blight. Extensive plantations of lodgepole pine in northwest British Columbia have resulted in a shift in species composition from lodgepole pine comprising $9 \%$ in native forests to $36 \%$ in plantations (43). This, together with a marked increase in the frequency of weather events favorable to the disease, has resulted in unprecedented levels of Dothistroma infection $(31,40)$. The results of this study support previous reports that the creation of extensive plantations of lodgepole pine has favored disease spread because of the close proximity of host foliage. The most effective disease management strategy for these forests is to significantly limit the use of lodgepole pine for reforestation and instead rely on more ecologically suitable species. If lodgepole pine is used for plantations in this area, it should be mixed with a large component of nonsusceptible trees to serve as barriers against spore transport from an inoculum source to susceptible trees. The extension of branches of susceptible trees reduces source to target distances when there is a large component of susceptible trees in a stand (5). An increase in the distance between susceptible trees reduces the likelihood of disease spread by rain-splashed spores (20).

In areas where Dothistroma needle blight is uncommon and lodgepole pine is ecologically suitable, fewer stems per hectare and greater intertree spacing may help reduce disease development and spread, at least during summers when conditions do not favor a widespread epidemic. However, there are other pathogens of lodgepole pine such as stem rust fungi for which higher densities are often prescribed to compensate for mortality and to enhance self-thinning (38). Prescriptions that affect stand density must be carefully considered in view of all potential forest health problems. Pruning of lodgepole pine trees in these forest types might also help reduce spread of the disease because infected needles, which serve as inoculum sources for new infection, are removed. Dead needles retained or hung up in the tree have been shown to be the chief means of dispersal of the pathogen within trees (22). The absence of pruning in forest plantations creates conducive conditions for the buildup of inoculum because of the moist and high-humidity conditions created within the canopy of forest stands $(19,39)$. Pruning helps to eliminate previously infected needles, which reduces inoculum volume (32). The distance between neighboring tree branches is also increased in pruned stands, which reduces the likelihood of successful dispersal. However, pruning is likely useful only in situations with low levels of disease and is probably not effective in epidemic situations, when there is a very heavy inoculum load.

Chemical control through the application of copper-based fungicides has proven to be effective in controlling the disease in countries such as New Zealand, Australia, and Chile $(8,20)$. In Nebraska, a single fungicide application in June provided efficient control of Dothistroma needle blight in pine plantations (34). Investigations conducted by Bingzhang et al. (5) in China also showed average efficiency of chemical control was $>60 \%$. However, in these cases, pine plantations were on private land under management only for the timber resource and were easily accessed for treatments. Chemical control of the fungus in pine plantations is not recommended in British Columbia because forest land is managed for multiple values, and the area of forest is vast. Application of chemical sprays would be expensive, with greater potential for negative environmental impacts. Therefore, the use of silvicultural management strategies and planting of resistant pine tree species or non-pine tree species are the best alternative methods to reduce the spread of the disease in the province.

\section{ACKNOWLEDGMENTS}

We thank B. Aukema and P. Jackson for their advice and suggestions during development and implementation of this research; and C. Konchalski, K. Hrinkevich, J. Orlowsky, S. Storch, D. Thompson, and staff of the British Columbia Ministry of Forests and Range in the Smithers office, especially A. Woods and E. Havard, for their logistical and technical assistance. Funding for this research was provided by the British Columbia Ministry of Forests and Range and an NSERC Discovery Grant.

\section{LITERATURE CITED}

1. Agrios, G. N. 2005. Pages 250-257 in: Plant Pathology, 5th ed. Academic Press, San Diego, CA.

2. Allen, E. A., Morrison, D. J., and Wallis, G. W. 1996. Common Tree Diseases of British Columbia. Natural Resources Canada, Canadian Forest Service, Victoria, BC, Canada.

3. Banner, A., MacKenzie, W., Haeussler, S., Thomson, S., Pojar, J., and Trowbridge, R. 1993. A field guide to site identification and interpretation for the Prince Rupert Forest Region. British Columbia Ministry of Forests, Land Management Handbook 26, Victoria, Canada

4. Barnes, I., Crous, P. W., Wingfield, B. D., and Wingfield, M. J. 2004. Multigene phylogenies reveal that red band needle blight of Pinus is caused by two distinct species of Dothistroma, D. septosporum and D. pini. Stud. Mycol. 50:551-565.

5. Bingzhang, H., Xinglin, D., Chengyu, L., Guigin, L., and Yuping, Y. 1992. The development pattern of Dothistroma needle blight and its control. J. Northeast For. Univ. 3:43-53.

6. Bradshaw, R. E. 2004. Dothistroma (red-band) needle blight of pines and the dothistromin toxin: A review. For. Pathol. 34:163-185.

7. Braun, C. 2009. The role of weather and topography in the development of Dothistroma septosporum. MSc thesis, University of Northern British Columbia, Prince George, BC, Canada.

8. Brown, A., and Webber, J. 2008. Red band needle blight of conifers in 
Britain. UK Forestry Commission Research Note. www.forestry.gov.uk/ pdf/FCN002.pdf/\$FILE/ FCRN002.pdf

9. Bulman, L. S., Gadgil, P. D., Kershaw, D. J., and Ray, J. W. 2004. Assessment and control of Dothistroma needle blight. For. Res. Bull. 229.

10. Cobb, F., Uhrenholdt, B., Krohn, R. 1969. Epidemiology of Dothistroma pini needle blight on Pinus radiata. (Abstr.) Phytopathology 59:1021.

11. Cooke, D. M., Gareth D. J., and Kaye, B. 2006. The Epidemiology of Plant Diseases, 2nd ed. Springer, Netherlands.

12. Dale, A. L., Lewis, K. J., and Murray, B. W. 2011. Sexual reproduction and gene flow in the pine pathogen Dothistroma septosporum in British Columbia. Phytopathology 101:68-76.

13. European and Mediterranean Plant Protection Organization (EPPO)/CABI. 1997. Quarantine Pests for Europe, 2nd ed. CABI International, Wallingford, UK

14. Evans, H. C. 1984. The genus Mycosphaerella and its anamorphs Cercoseptoria, Dothistroma and Lecanosticta on pines. CMI Mycol. Pap. No 153. Commonwealth Mycological Institute, Surrey, UK.

15. Fitt, B. D. L., McCartney, H. A., and Walklate, P. J. 1989. The role of rain in dispersal of pathogen inoculum. Annu. Rev. Phytopathol. 27:241-270.

16. Fournet, J. 1969. Propriétés et role du cirrhe du Septoria nodorum Berk. Ann. Phytopathol. 1:87-94.

17. Funk, A. 1985. Foliar Fungi of Western Trees. Agriculture Canada, Ministry of State for Forestry, Pacific Forest Research Centre, Victoria, BC, Canada. Inf. Rep. BC-X-265.

18. Funk, A., and Parker, A. K. 1966. Scirrhia pini N. sp., the perfect state of Dothistroma pini Hulbary. Can J. Bot. 44:1171-1176.

19. Gadgil, P. D. 1984. Dothistroma needle blight. In: Forest Pathology in New Zealand, No. 5. New Zealand Forest Service, Rotorua, New Zealand.

20. Gadgil, P. D., and Bain, J. 1999. Vulnerability of planted forest to biotic and abiotic disturbances. New For. 17:227-238.

21. Gibson, I. A. S. 1972. Dothistroma blight of Pinus radiata. Annu. Rev. Phytopathol. 10:51-72.

22. Gibson, I. A. S. 1974. Impact and control of Dothistroma blight of pines. Eur. J. For. Pathol. 4:89-100.

23. Gibson, I. A. S., Christensen, P. S., and Munga, F. N. 1964. First observations in Kenya on a foliage disease of pines, caused by Dothistroma pini Hulbary. Commonwealth For. Rev. 43:31-48.

24. Gilmour, J. W., and Crockett, F., 1972. Dothistroma pini project: Monitoring of infection patterns in the field. In: Report of the Forest Research Institute of New Zealand, Rotorua, NZ.

25. Groenewald, M., Barnes, I., Bradshaw, R. E., Brown A. V., Dale, A., Groenewald, J. Z., Lewis, K. J., Wingfield, B. D., Wingfield, M. J., and Crous, P. W. 2007. Characterization and distribution of mating type genes in the Dothistroma needle blight pathogens. Phytopathology 97:825-834.

26. Hirst, P., Richardson, T., Carson, S., and Bradshaw, R. 1999. Dothistroma pini genetic diversity is low in New Zealand. N.Z. J. For. Sci. 29:459-472.
27. Hunt, R. S. 1995. Common pine needle casts and blights in the Pacific region. Forest Pest Leaflet 43, Natural Resources Canada. Pacific Forestry Centre, Victoria, BC.

28. Karadzic, D. 1989. Scirrhia pini Funk et Parker. Life cycle of the fungus in plantations of Pinus nigra Arn. in Serbia. Eur. J. For. Pathol. 19:231236.

29. Karadzic, D. 1994. A new host of Dothistroma septospora. Eur. J. For. Pathol. 24:300-303.

30. Markovskaja, S., and Treigienè, A. 2009. New data on invasive pathogenic fungus Dothistroma septosporum in Lithuania. Bot. Lith. 15:41-45.

31. McCulloch, L., and Woods, A. 2009. British Columbia's northern interior forests: Dothistroma stand establishment decision aid. BC JEM 10:1-3.

32. Meredith, D. S. 1973. Significance of spore release and dispersal mechanisms in plant disease epidemiology. Annu. Rev. Phytopathol. 11:313342.

33. Parker, A. K., and Collins, D. G. 1966. Dothistroma needle blight of pines in British Columbia. For. Chron. 42:160-161.

34. Peterson, G. W. 1967. Dothistroma needle blight of Austrian and ponderosa pines: Epidemiology and control. Phytopathology 57:437-441.

35. Peterson, G. W. 1973. Infection of Austrian and ponderosa pines by Dothistroma pini in Eastern Nebraska. Phytopathology 63:1060-1063.

36. Podger, F. D. 1978. Studies on the effect of some climatic factors and spore dispersal on infection of two species of Pinus by Dothistroma pini. Ph.D. thesis, University of Auckland, New Zealand.

37. Shaw, M. W., and Royle, D. J. 1993. Factors determining the severity of epidemics of Mycosphaerella graminicola (Septoria tritici) on winter wheat in the UK. Plant Pathol. 42:882-899.

38. Swift, K., Turner, J., and Rankin, L. 2002. Cariboo forest region: Part 1 of 3. Forest health stand establishment decision aids. BC JEM 2:13-18.

39. Villebonne, D., and Maugard, F. 1999. Rapid development of Dothistroma needle blight (Scirrhia pini) on Corsican pine (Pinus nigra subsp. laricio) in France. Pages 30-32 in: La Santé des Forêts, Annual Report 1998, Les Cahiers du DSF 1, DERF, Paris

40. Welsh, C., Lewis, K., and Woods, A. 2009. The outbreak history of Dothistroma needle blight: An emerging forest disease in northwestern British Columbia, Canada. Can. J. For. Res. 39:2505-2519.

41. Welsh, C., Lewis, K., and Woods, A. 2014. Regional outbreak dynamics of Dothistroma needle blight linked to weather patterns in British Columbia, Canada. Can. J. For. Res. 44:212-219.

42. Westfall, J., and Ebata, T. 2007. Summary of forest health conditions in British Columbia. Pest Management Report Number 15. Bristish Columbia Ministry of Forests and Range, Forest Practices Branch, Victoria, BC.

43. Woods, A. J. 2003. Species diversity and forest health in northern British Columbia. For. Chron. 79:892-897.

44. Woods, A. J., Coates, K. D., and Hamann, A. 2005. Is an unprecedented Dothistroma needle blight epidemic related to climate change? Bioscience 55:761-769 